pemphigus vulgaris : pentingnya diagnosis dini

Indonesian Journal of Dentistry 2009; 16 (1):1-7

http//www.fkg.ui.edu

Fakultas Kedokteran Gigi

Universitas Indonesia

ISSN 1693-9697

\title{
PEMPHIGUS VULGARIS : PENTINGNYA DIAGNOSIS DINI, PENATALAKSANAAN YANG KOMPREHENSIF DAN ADEKUAT (Laporan Kasus)
}

\author{
Sri Rezeki* Titiek Setyawati** \\ * Residen Departemen Ilmu Penyakit Mulut, Fakultas Kedokteran Gigi, \\ Universitas Indonesia \\ **Staf Pengajar Departemen Ilmu Penyakit Mulut, Fakultas Kedokteran Gigi, \\ Universitas Indonesia
}

\begin{abstract}
Pemphigus vulgaris is an autoimmune-mediated disease of skin and mucous membran leading to progressive blistering and chronic erosions. It often begins with blister formations which easily rupture. The characteristic feature is positive nikolsky sign which may or not be presented simultaneously. Infrequently, ocular involvement may be seen as conjunctivitis. Establishment of early definite diagnosis is critical and requires correlation of clinical and histopathological findings. Because of this conditon is a potentially life-threatening, the risk of complications and mortality rate increases if initial management is non comprehensive and inadequate. Treatment is directed at supression of autoimmune process, typically administration of corticosteroids. This article report a case in a 51 years old woman who had painful chronic oral ulcer and poor general health condition. Prior to the visit to Oral Medicine clinic, patient was treated by her general practitioners for several months, without either established diagnosis nor comprehensive and adequate management, so that she had no clinical improvement. Clinical examination at the first visit in Oral Medicine clinic Cipto Mangunkusumo Hospital, revealed bula in the skin, conjunctivitis, easily bleed oral mucosae, widespread erosions and ulcerations of the lips, gingiva, tongue, and buccal mucosae. Biopsy of one of skin erosions demonstarting suprabasal intraepithelial acantholysis. Multi divisions in Cipto Mangunkusumo Hospital, such as Oral Medicine, Dermatology, Internal Medicine, Ophtalmology, ENT, were involved in treating this case. Patient received high dose methylprednisolone sistemically and prednisone topically for the lips. General remission achieved in several days. Thus, establishment of early definite diagnosis and adequate management are important in management of Pemphigus vulgaris.
\end{abstract}

Keywords : pemphigus vulgaris, early diagnosis, management. 


\section{Pendahuluan}

Pemphigus vulgaris merupakan penyakit autoimun dengan manifestasi berupa kondisi lepuhan pada permukaan kulit dan atau mukosa. $^{1-3}$ Hal ini dapat terjadi karena kerusakan atau hilangnya adhesi intersel ${ }^{4}$ akibat autoantibodi IgG, ${ }^{4,5}$ kadang-kadang IgA dan $\operatorname{IgM}^{5}$ terutama terhadap desmoglein $3,{ }^{1,5,6}$ dapat juga pada desmoglein $1,{ }^{1}$ sehingga menyebabkan pelepasan sel epitel yang dikenal dengan akantolisis. ${ }^{4}$ Perluasan ulserasi yang diikuti ruptur pada lepuhan dapat menyebabkan rasa sakit, kehilangan cairan dan elektrolit. ${ }^{4}$

Pemphigus vulgaris berpotensi mengancam jiwa. ${ }^{1,7,8}$ Penyakit ini dapat melemahkan kondisi pasien ${ }^{4}$ dan sering menyebabkan kematian. ${ }^{9}$ Apabila tidak dirawat dengan tepat, maka lesi akan menetap dan semakin meluas, ${ }^{10}$ menyebabkan kerusakan kulit dan membran mukosa sehingga dapat terjadi kehilangan cairan dan ketidakseimbangan elektrolit ${ }^{4,11}$ infeksi, ${ }^{11}$ bahkan sepsis. ${ }^{12}$ Sebelum ditemukan perawatan yang efektif, angka kematian mencapai $90 \%$. $^{3}$ Apabila dirawat dengan tepat angka kematian hanya sekitar 5-10\%. ${ }^{10,13}$

Dalam laporan ini akan dibahas suatu kasus Pemphigus vulgaris yang diawali oleh lesi mulut sebelum terjadi lesi di bagian tubuh lain. Karena tidak terdiagnosis secara dini dan penatalaksanaan sebelumnya tidak komprehensif dan adekuat menyebabkan kondisi umum buruk.

Penatalaksanaan yang komprehensif berupa kerjasama terpadu antara divisi Penyakit Mulut, Kulit Kelamin, Penyakit Dalam, THT, keadaan umum pasien membaik, sehingga mempersingkat waktu perawatan dan mengurangi penderitaan yang dialami pasien.

\section{Laporan Kasus}

Pada tanggal 29 April 2008, seorang pasien perempuan berusia 51 tahun dirujuk dari RSUD B.A dengan diagnosis kerja stomatitis kronis. Dari anamnesis diperoleh informasi bahwa pasien tidak dapat menelan dan berbicara selama 18 bulan terakhir karena terdapat lukaluka di dalam mulut yang terasa sangat sakit. Oleh karena itu, prosedur pembersihan gigi dan mulut sehari-hari tidak pernah dilakukan. Luka pada awalnya terdapat di mulut berupa sariawan ukuran kecil pada lidah bagian atas, terasa sakit tanpa diawali demam. Satu bulan pertama pasien mengkonsumsi larutan penyegar 3 sampai 4 kaleng perhari dengan tujuan menghilangkan keluhan sariawan, namun bertambah banyak disertai rasa sakit menelan. Pada saat itu belum terjadi lepuhan di kulit.

Kemudian pasien dirawat inap di Rumah Sakit Kabupaten setempat selama 2 minggu, diberikan obat minum berupa tablet. Sariawan semakin bertambah banyak. Pasien memutuskan untuk pulang dan menjalani pengobatan alternatif selama 1.5 bulan. Sariawan terus bertambah banyak dan mulai timbul lepuhan di kulit yang muncul 3 bulan setelah keluhan di rongga mulut. Selama perawatan ini, terdapat pembesaran kelenjar yang diduga kelenjar submandibula dan menyebabkan pasien dirujuk ke Rumah Sakit Propinsi dengan dugaan tumor. Dilakukan biopsi aspirasi pada kelenjar tersebut dengan hasil tidak ditemukan tumor. Pasien dirawat inap selama 42 hari dengan pengobatan berupa pil lebih dari 5 macam. Kelenjar mengecil, tetapi sariawan dan lepuhan di kulit bertambah banyak. Selanjutnya pasien menjalani rawat jalan selama 1 bulan. Pasien kembali rawat jalan di Rumah Sakit Kabupaten selama 14 bulan dan 4 hari terakhir dirawat inap dengan diagnosis kerja Pemphigus.

Pengobatan yang diterima adalah antibiotik golongan siprofloksasin dan desoksimetason salep selama 1 tahun, obat kumur yang mengandung povidon yodium dan antijamur nistatin. Karena dari perawatan yang didapat tidak ada perbaikan, pasien dirujuk ke bagian Penyakit Mulut RSCM.

Pada kunjungan pertama di bagian Penyakit Mulut RSCM, berdasarkan pemeriksaan subjektif aloanamnesis dan autoanamnesis, terdapat luka di mulut yang sangat sakit sehingga menyebabkan pasien tidak bisa berbicara, menelan dan membuka mulut. Kuku pecah-pecah dan pernah lepas dengan sendirinya. Mata terasa perih, merah dan 
belekan sejak 3 bulan yang lalu. Pada pemeriksaan objektif, terlihat kondisi umum pasien lemah, menggunakan kursi roda, asupan makanan menggunakan naso gastric tube (NGT). Telapak tangan terdapat daerah erosi. Jari tangan dan kaki terdapat bula dan erosi, kuku terlihat distrofik (Gambar 1.a). Pada mata terdapat eksudat dan kemerahan di konjungtiva dan palpebra (Gambar 1.b). Dari pemeriksaan ekstra oral, tampak beberapa daerah erosi pada kulit wajah. Bibir atas dan bawah terdapat krusta, hemorrhagic area, edema dan erosi (Gambar 1.c). Pemeriksaan intra oral baru dapat dilakukan setelah aplikasi anestetikum topikal karena kesulitan membuka mulut. Pemeriksaan tidak optimal karena mukosa mulut mudah berdarah. Keadaan kebersihan mulut buruk dengan kalkulus sub dan supra gingiva, stain dan debris dalam jumlah yang banyak. Terlihat erosi multipel dan daerah eritematus pada mukosa labial, bukal, gingiva, lidah, dan palatum (Gambar 2.a-c). Terdapat Massa eksofitik pada mukosa bukal kiri dan lidah. Beberapa gigi goyang derajat 2 .

Diagnosis yang ditegakkan saat itu adalah Pemphigus vulgaris dengan diagnosis banding mucous membran pemphigoid. Dugaan fibroma pada mukosa bukal kiri dan lidah, periodontitis kronis pada gigi-gigi yang goyang. Pasien dan pendamping diinstruksi untuk mengupayakan pembersihan gigi dan mulut semaksimal mungkin dan diberi medikasi berupa obat oles yang mengandung prednison dan anestetikum topikal untuk lesi di bibir. Kemudian pasien dirujuk ke bagian kulit dan dirawat inap.

Di bagian kulit dilakukan biopsi dengan gambaran histopatologi adanya cleft suprabasal pada epidermis yang juga terdapat di sekeliling folikel. Dermis atas sembab, bersebukan limfosit, eosinofil dan PMN yang sesuai dengan Pemphigus vulgaris (Gambar 1.d). Perawatan yang diberikan adalah metilprednisolon secara intra vena 2 x 31.25mg perhari selama 6 hari, dilanjutkan dalam bentuk tablet yang setara dengan prednison 60mg selama 6 hari, diikuti penurunan dosis. Bula dikompres dengan larutan $\mathrm{NaCl}$ 0.9\% 2 kali perhari, sedangkan lesi erosi kulit diberi silver sulfadiazine salep. Diberikan antibiotik golongan klindamisin selama 3 hari, tablet kalsium karbonat, kalsitriol, ranitidin dan diit cair.

Pada bagian mata, diagnosis yang ditegakkan adalah blefarokonjungtivitis dan dari bagian THT didiagnosis odinofagi et causa Pemphigus vulgaris. Dari bagian penyakit dalam sub bagian kardiologi, pada hari kelima perawatan, pasien didiagnosis hipertensi grade II dengan tekanan darah 150/100 mmHg. Dari sub bagian pulmonologi didiagnosis bronkopneumoni dengan diagnosis banding tuberkulosis paru.

Pada kontrol hari keempat, kondisi umum pasien masih lemah, NGT masih terpasang, konjungtiva dan palpebra merah. Terdapat bula baru pada daerah pergelangan tangan kanan (Gambar 1.e). Pada pemeriksaan ekstra oral, kulit wajah masih terdapat daerah erosi, bibir masih terdapat krusta kehitaman, sedangkan hemorrhagic area sudah berkurang. Pasien sudah dapat membuka mulut tanpa pemberian anestetikum topikal. Mukosa labial, bukal, gingiva, palatum, lidah dan dasar mulut masih terlihat daerah erosi dan ulserasi (Gambar 2.df). Aplikasi obat oles bibir mengandung prednison diteruskan. Di bagian rawat inap, medikasi yang diberikan adalah metilprednisolon secara intra vena, antibiotik golongan klindamisin, salep kulit silver sulfadiazine, obat mata oksitetrasiklin dan cenfresh $^{\mathrm{TM}}$.

Pada kontrol hari kelimabelas, kondisi umum pasien membaik dan NGT sudah dilepas sejak hari ketujuh. Konjungtiva dan palpebra tidak terlihat kemerahan, bula di jari dan pergelangan tangan serta kaki tidak ditemukan lagi, daerah erosi pada tangan dan kaki berkurang. Pada pemeriksaan ekstra oral, kulit wajah tidak terlihat daerah erosi. Krusta dan daerah erosi pada bibir tidak ditemukan (Gambar 1.f). Pada pemeriksaan intra oral, erosi mukosa labial, bukal, gingiva, lidah dan dasar mulut berkurang (Gambar 2.g). Ditemukan plak putih dapat diangkat, meninggalkan daerah kemerahan, sakit, pada mukosa bukal, lidah bagian dorsum (Gambar 2.h,i). Diagnosis Pemphigus vulgaris rongga mulut penyembuhan disertai kandidiasis. Perawatan tambahan dari bagian penyakit mulut adalah obat antijamur 
nistatin suspensi. Pasien masih diberikan metilprednisolon tetapi dalam bentuk tablet yang sudah dimulai sejak hari ketujuh.

Pada kontrol hari keduapuluhsatu, kondisi umum dan temuan ekstra oral masih seperti kontrol sebelumnya. Pada pemeriksaan intra oral, mukosa mulut tidak mudah berdarah, daerah erosi pada mukosa labial atas (Gambar 2.j) dan bawah, mukosa bukal, lidah, palatum dan dasar mulut berkurang serta tidak ditemukan plak putih seperti sebelumnya (Gambar 2.k). Obat oles bibir mengandung prednison dan nistatin suspensi dilanjutkan. Perawatan dari bagian kulit adalah tablet metilprednisolon, levofloksasin, azitromisin, obat antihipertensi, kalsitriol, kalsium karbonat, ranitidin. Secara umum, kondisi pasien dinilai baik sehingga diperkenankan pulang dan diteruskan dengan rawat jalan. Dalam upaya peningkatan kebersihan rongga mulut, pasien dilakukan skeling dan pencabutan gigi. Kondisi ekstra oral dan intra oral pada hari keduapuluhtujuh dapat dilihat pada gambar 1.g-i dan 2.l,m.

\section{Pembahasan}

Berdasarkan kasus di atas, dapat dilihat penegakan diagnosis sedini mungkin sangat penting agar perawatan yang sesuai dapat diberikan. Apabila terjadi kesalahan diagnosis, perawatan yang diberikan menjadi berkepanjangan dan tidak adekuat sehingga risiko komplikasi meningkat. ${ }^{3}$ Sebelumnya pasien menjalani perawatan selama 18 bulan, tetapi baru 3 minggu terakhir dinyatakan Pemphigus tanpa tindakan biopsi. Penegakan diagnosis Pemphigus vulgaris memerlukan korelasi antara penemuan klinis dan histopatologis. ${ }^{3,14}$ Prognosis dinyatakan baik apabila penegakan diagnosis dan perawatan dilakukan sedini mungkin. ${ }^{14}$

Pada bagian penyakit mulut, berdasarkan anammesis dan pemeriksaan klinis diagnosis awal pasien adalah Pemphigus vulgaris. Pasien ini perempuan berusia 51 tahun. Pemphigus vulgaris merupakan penyakit yang sering mengenai perempuan usia pertengahan. ${ }^{11}$
Berdasarkan anamnesis terdapat keluhan luka di mulut yang menetap dan bertambah parah, terasa sangat sakit sehingga pasien tidak dapat makan dan berbicara. Lesi Pemphigus vulgaris cenderung sakit dan mengganggu fungsi penting rongga mulut. ${ }^{15}$ Menurut pasien, 3 bulan setelah sariawan di mulut, muncul lepuhan di kulit. Gambaran khas berupa Nikolsky sign positif, ${ }^{9}$ yaitu terjadi pemisahan lapisan luar epidermis dari lapisan basal dengan tekanan geser menggunakan jari sehingga terjadi erosi atau perluasan bula ke arah lateral apabila ditekan. ${ }^{6}$ Sekitar 60\% kasus Pemphigus vulgaris, lesi rongga mulut mengawali lesi kulit, ${ }^{9,14} 56 \%$ kasus dengan lesi hanya di rongga mulut, 32\% lesi intra oral disertai salah satu bagian kulit, $12 \%$ hanya memiliki lesi di kulit. ${ }^{14}$ Pemeriksaan klinis rongga mulut menunjukkan hampir seluruh mukosa terdapat erosi multipel, mudah berdarah (hemorrhagic area) dan ulserasi difus dengan tepi ireguler. Lesi pada awalnya dapat berupa vesikel ${ }^{16}$ dan bula ${ }^{10,16}$ dengan ukuran lebih besar dari 1 sentimeter ${ }^{10}$ yang mudah ruptur membentuk ulser dangkal ${ }^{10,16}$ dilapisi pseudomembran keabuan. ${ }^{10}$ Membran dapat dilepaskan sehingga terlihat permukaan eritematus. ${ }^{10}$ Ulser dirasakan sangat sakit dan dapat ditemui pada permukaan epitel, seperti rongga mulut, esofagus, laring, faring, kulit, vagina, anus dan mata. ${ }^{10}$

Konfirmasi diagnosis melalui tindakan biopsi kulit yang dilakukan pada hari kedua, dengan hasil pembacaan bagian patologi anatomi sesuai Pemphigus vulgaris. Oleh karena beberapa lesi vesikulobulosa dan ulserasi memiliki tampilan yang serupa, seperti Pemphigoid, Lichen planus tipe erosif dan Erythema multiforme, maka penegakan diagnosis tidak hanya didasarkan pada pemeriksaan klinis. $^{2}$ Untuk memastikan diagnosis Pemphigus vulgaris diperlukan pemeriksaan histopatologi, ${ }^{12}$ dengan karakteristik berupa cleft intra epitel atau akantolisis suprabasal ${ }^{10,17}$ dan sel epitel membulat, dikenal dengan Tzanck cells. ${ }^{10}$ Pada pasien ini gambaran mikroskopik epidermis tampak cleft suprabasal yang ditemukan juga di sekeliling folikel. 


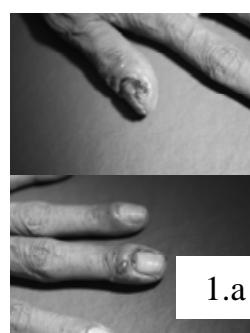

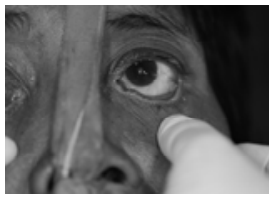

1.b

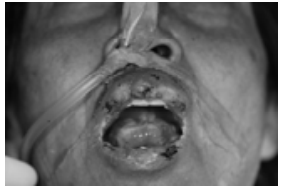

1.c

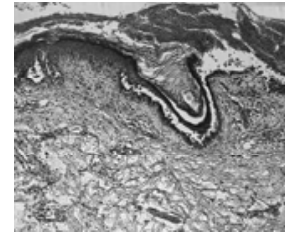

1.d

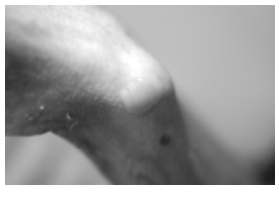

1.e

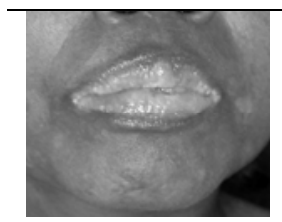

1.f

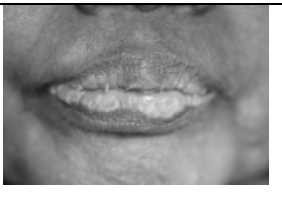

1.9
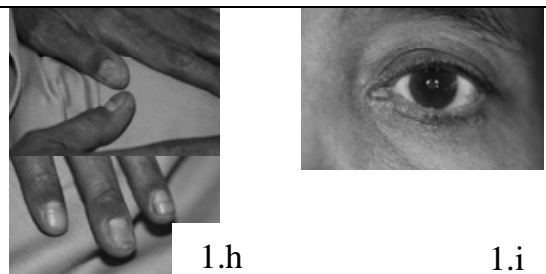

$1 . \mathrm{i}$

Gambar 1. Ekstra Oral dan Histopatologi

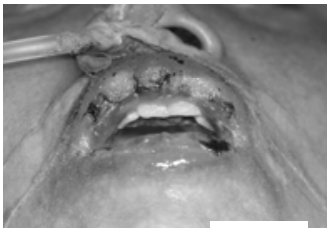

2.a
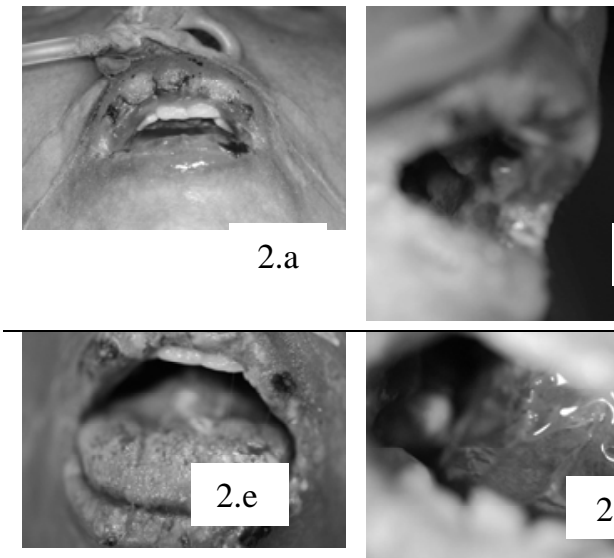

2.b
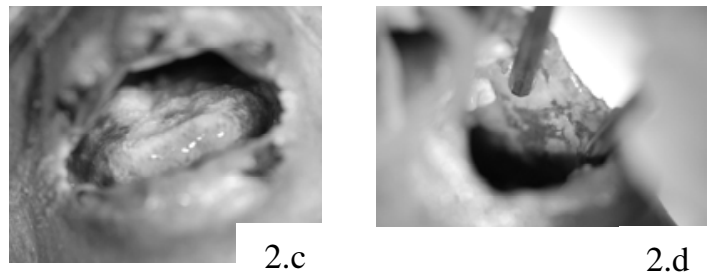

2.d
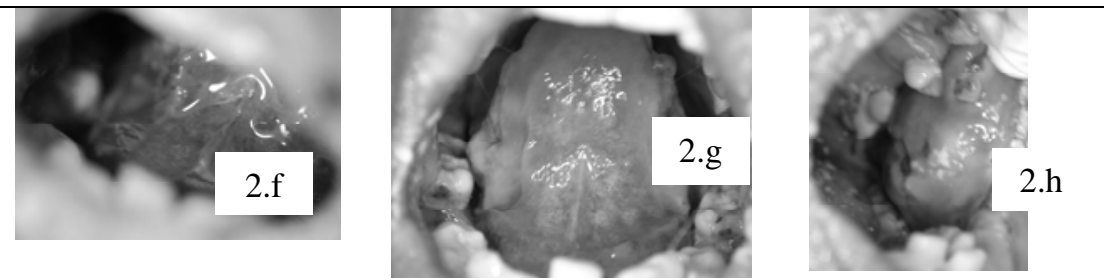
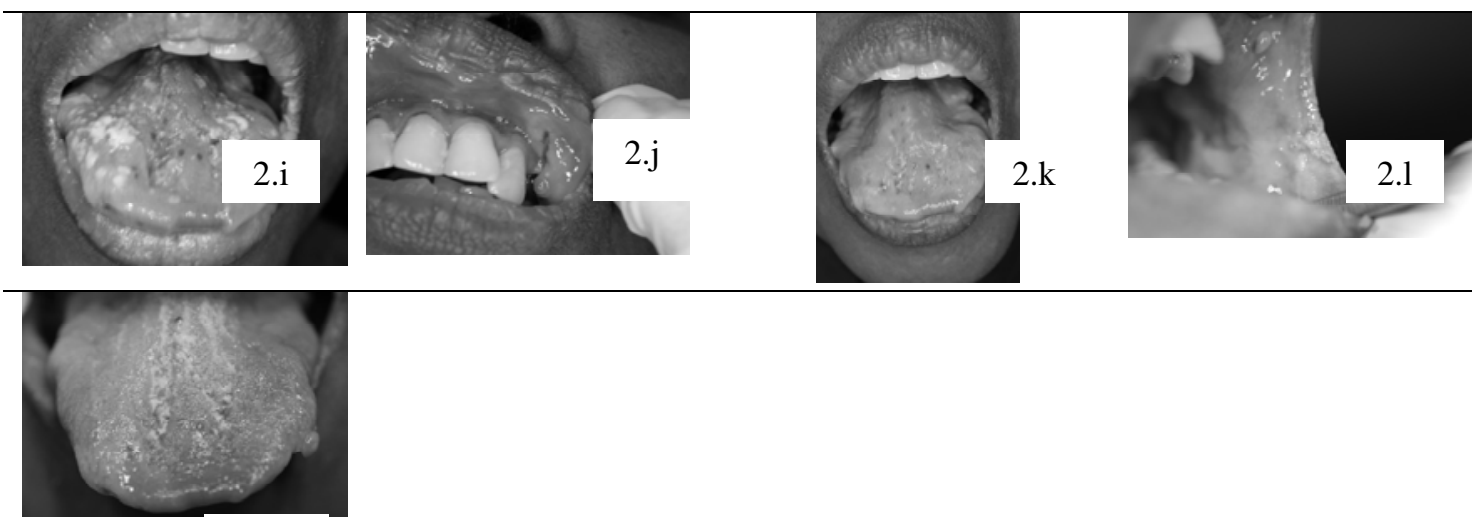

2.m

Gambar 2. Intra Oral 
Keluhan pasien berupa mata merah, berdarah, perih timbul sekitar 15 bulan setelah luka di mulut. Beberapa kasus Pemphigus vulgaris dengan keterlibatan okular telah dilaporkan. ${ }^{18}$ Palpebra dan konjungtiva terlihat hiperemi, sehingga pasien dirujuk ke bagian mata untuk dilakukan pemeriksaan dan penatalaksanaan lebih lanjut. Karakteristik keterlibatan Pemphigus vulgaris pada mata adalah konjungtivitis dengan hiperemi dan perubahan mukoid. ${ }^{18}$ Penyakit ini dapat menyebabkan deskuamasi kornea berat dan adhesi konjungtiva, bahkan dapat menyebabkan kebutaan fungsional. ${ }^{2}$ Keluhan pada mata umumnya membaik dengan perawatan kortikosteroid sistemik. ${ }^{18}$

Pasien segera dirawat inap dan ditangani secara komprehensif dengan melibatkan bagian penyakit mulut, kulit dan kelamin, mata, penyakit dalam serta THT. Perawatan terutama diarahkan untuk menekan proses autoimun, ${ }^{3}$ yaitu dengan pemberian kortikosteroid sistemik, ${ }^{2,12}$ biasanya dalam dosis 1 sampai 2 mg/kgBB/hari. ${ }^{12}$ Pasien Pemphigus vulgaris yang parah atau berkembang cepat, memerlukan kortikosteroid dosis tinggi yang cara pemberiannya tergantung pada keparahan penyakit. ${ }^{14}$ Beberapa bukti menyatakan bahwa kortikosteroid dosis tinggi dapat mengendalikan akantolisis karena memiliki sifat imunosupresif dan efek langsung antiakantolisis pada keratinosit. ${ }^{7}$ Pasien ini selama 6 hari pertama dirawat dengan kortikosteroid, yaitu metilprednisolon 2 x $31.25 \mathrm{mg}$ secara intra vena dan dilanjutkan dalam bentuk tablet. Metilprednisolon dapat menghambat akantolisis pada kulit yang diinduksi oleh IgG. $^{7}$ Bibir pasien diberikan obat oles racikan mengandung prednison sehingga daerah erosi dan ulserasi teratasi. Dengan adanya perbaikan pada bibir, aktivitas berbicara dan pembersihan rongga mulut dapat dilakukan kembali.

Efek samping terkait pemberian kortikosteroid dosis tinggi dalam jangka panjang, seperti hipertensi, perdarahan gastrointestinal, osteoporosis, hiperglikemia ${ }^{14}$ ditangani oleh bagian penyakit dalam. Efek samping lainnya adalah kandidiasis, ${ }^{19}$ yang terlihat secara klinis di rongga mulut pasien pada hari kelimabelas perawatan dengan kortikosteroid, berupa plak putih dapat diangkat, meninggalkan daerah kemerahan dan rasa perih pada mukosa bukal dan dorsum lidah. Pasien diberikan obat antijamur topikal, yaitu nistatin suspensi. Secara klinis, terlihat perbaikan 7 hari setelah pemakaian obat antijamur tersebut.

Kebersihan mulut yang optimal sangat penting di dalam perawatan ini. Keterlibatan gingiva dan jaringan periodontal dapat memberikan respon berlebihan terhadap plak bakteri. Dalam hal ini, perawatan gigi dan mulut bertujuan untuk mengurangi produksi autoantibodi sistemik sehingga diharapkan dapat mengendalikan proses penyakit. ${ }^{14}$ Pasien yang sebelumnya tidak pernah melakukan prosedur pembersihan gigi dan mulut selama 18 bulan, diinstruksi untuk tetap mengupayakannya, diawali aplikasi anestetikum topikal apabila pembukaan mulut dirasakan sakit. Prosedur dimulai dengan tindakan pembersihan gigi dan mulut secara lembut menggunakan kasa yang dibasahi air secara perlahan. Apabila keadaan mukosa mulut sudah tidak mudah berdarah, dilanjutkan dengan pemakaian sikat gigi tanpa pasta terlebih dahulu sehingga diharapkan tidak mengiritasi bagian yang sedang mengalami erosi. Setelah mukosa terlihat lebih utuh, tanpa erosi yang meluas, maka pasta gigi dapat digunakan. Skeling dan pencabutan gigi dilakukan ketika masalah sistemik sudah ditangani bagian penyakit dalam dengan harapan risiko komplikasi akibat tindakan invasif di bidang kedokteran gigi terkait kondisi sistemik pasien dapat dikurangi.

\section{Kesimpulan}

Pemphigus vulgaris merupakan suatu penyakit autoimun mukokutaneus kronis yang menyebabkan pembentukan bula progresif dan erosi kronis. Gambaran khas berupa pemisahan lapisan luar epidermis dengan tekanan geser menggunakan jari sehingga menyebabkan terjadi erosi atau apabila bula ditekan terjadi perluasan ke lateral, dikenal dengan Nikolsky sign positif. Pada rongga mulut lesi terlihat 
berupa erosi dan ulserasi pada mukosa. Gambaran khas secara histopatologis terlihat cleft intra epitel atau akantolisis epitel suprabasal dengan sel membulat, disebut Tzanck cells. Selain berdasarkan penemuan klinis, penegakan diagnosis ditunjang dengan gambaran histopatologis untuk eksklusi penyakit lain yang secara klinis menyerupai Pemphigus vulgaris. Penyakit ini memiliki angka kematian cukup tinggi apabila tidak dirawat dengan tepat. Oleh karena itu diagnosis, perawatan adekuat dan terpadu harus dimulai sedini mungkin, dengan melibatkan berbagai disiplin ilmu terkait secara komprehensif, sehingga risiko komplikasi yang bersifat fatal dapat diturunkan.

\section{Daftar Pustaka}

1 Scully C, Challacombe SJ. Pemphigus vulgaris: update on etiopathogenesis, oral manifestations, and management. Crit Rev Oral Biol Med 2002; 13 (5): 397-408.

2 Sirois D, Leigh JE, Sollecito TP. Oral pemphigus vulgaris preceding cutaneous lesions: recognition and diagnosis. JADA 2000; 131: 1156-60.

3 Robinson JC, Lozada-Nur F, Frieden I. Oral pemphigus vulgaris a review of the literature and a report on management of 12 cases. Oral Surg Oral Med Oral Pathol Oral Radiol Endod 1997; 84: 349-55.

4 Regezi JA, Sciubba JJ, Jordan RCK. Oral pathology clinical pathologic correlations, 4 ed. St. Louis, Missouri: Saunders, 2003.p.11-15

5 Silverman S, Eversole LR, Truelove EL. Essentials of oral medicine. London: BC Decker, 2001.p.202-4

6 Wolff K, Johnson RA. Fitzpatrick's color atlas \& synopsis of clinical dermatology, 5 ed. New York: McGraw-Hill, 2005.p.102-5
7 Nguyen VT, Arredondo J, Chernyavsky AI et al. Pemphigus vulgaris IgG and methylprednisolone exhibit reciprocal effects on keratinosit. JBC 2004; 279 (3): 2135-46.

8 Ahmed AR, Spigelman Z, Cavacini LA et al. Treatment of pemphigus vulgaris with rituximab and intravenous immune globulin. $N$ Engl $J$ Med 2006; 355: 1772-9.

9 Neville BW, Damm Dd, Allen CM et al. Oral \& maxillofacial pathology, 2 ed. Pennsylvania: Saunders, 2002.

10 DeLong L, Burkhart NW. General and oral pathology for the dental hygienist. Philadelphia: Lippincott Williams \& Wilkins, 2008.p.285-6

11 Scully C, Cawson RA. Medical problems in dentistry, 5 ed. New York: Elsevier, 2005.p.2704

12 Greenberg MS, Glick M. Burket's oral medicine diagnosis \& treatment, 10 ed. Ontario: BC Decker Inc, 2003.p.68-70

13 Scully C. Oral and maxillofacial medicine. New York Elsevier, 2004.p.366-72

14 Weinberg MA, Insler MS, Cmpen RB. Mucocutaneous features of autoimmune blistering diseases. Oral Med Oral Pathol Oral Radiol Endod 1997; 84: 517-34.

15 Chi AC, Ravenel MC, Neville BW et al. A patient with painful oral ulcers. JADA 2006; 137: 626-9.

16 Kumar V, Abbas AK, Fausto N. Robbins and cotran pathologic basis of disease, 7 edn.: Elsevier, 2005.

17 Lenz P, Amagai M, Volc-platzer B et al. Desmoglein 3-ELISA a pemphigus vulgarisspecific diagnostic tool. Arch dermatol 1999; 135: $143-8$.

18 Merchant S, Weinstein M. Pemphigus vulgaris: the eyes have it. Pediatrics 2003; 112: 183-5.

19 Sherman RG, Ravenel MC. Oral candidosis. Quintessence Int 2002; 33: 521-32. 